\title{
Evidence-Based Regulation and the Translation from Empirical Data to Normative Choices: A Proportionality Test
}

\author{
Rob van Gestel \& Peter van Lochem*
}

\begin{abstract}
Studies have shown that the effects of scientific research on law and policy making are often fairly limited. Different reasons can be given for this: scientists are better at falsifying hypothesis than at predicting the future, the outcomes of academic research and empirical evidence can be inconclusive or even contradictory, the timing of the legislative cycle and the production of research show mismatches, there can be clashes between the political rationality and the economic or scientific rationality in the law making process et cetera. There is one 'wicked' methodological problem, though, that affects all regulatory policy making, namely: the 'jump' from empirical facts (e.g. there are too few organ donors in the Netherlands and the voluntary registration system is not working) to normative recommendations of what the law should regulate (e.g. we need to change the default rule so that everybody in principle becomes an organ donor unless one opts out). We are interested in how this translation process takes place and whether it could make a difference if the empirical research on which legislative drafts are build is more quantitative type of research or more qualitative. That is why we have selected two cases in which either type of research played a role during the drafting phase. We use the lens of the proportionality principle in order to see how empirical data and scientific evidence are used by legislative drafters to justify normative choices in the design of new laws.
\end{abstract}

\section{Introduction}

Most legislative drafters in the Netherlands have a predominantly doctrinal perspective on law and legislation and have to learn most of the tricks of the trade of how to transform policy into law in daily practice. This is because law school training is still mainly focused on the role model of the judiciary and (doctrinal) textual interpretation methods of judges and solicitors. ${ }^{1}$ In the train-

Rob van Gestel is professor of theory and methods of regulation at Tilburg University and dr. Peter van Lochem is jurist and sociologist and former director of the Academy for Legislation. The authors wish to thank Thomas van Golen, PhD at Tilburg University's Law School, for his useful comments. The usual disclaimer applies.

1. J.B.M. Vranken, 'Methodology in Legal Research and Legal Practice. A Comparison of Judge and Legal Academic', in M. Groenhuijsen, E. Hon- ee programme for legislative drafters of the Academy for Legislation (AL) in The Hague, there is a bit more attention for the relationship between law and policy and for sociolegal research. ${ }^{2}$ Even in the curriculum of the AL, however, there is little attention of how to interpret and use empirical data in designing new laws and regulations. ${ }^{3}$ This is probably no different elsewhere in Europe, ${ }^{4}$ even though the ability to translate policy into law is seen as one of the most important talents that drafters should possess. In the United Kingdom, Page interviewed members of the Office of the Parliamentary Council responsible for legislative drafting. One of them formulated it as follows:

Sometimes you can recruit a wonderful young lawyer. You give them a draft that you have been working on and they rip it all apart brilliantly. But you give them a set of instructions and ask them to write a draft themselves and they sit staring at the wall and won't know where to start. It's an analytical thing, it is actually rather different from being just a good lawyer. ${ }^{5}$

One of the most difficult things for draftsmen to master is the analytical capacity to transform the objectives, logic and structure of what policymakers intend into a legislative language that is comprehensible, executable and enforceable. The importance of designing laws that will actually work is underlined by an increasing emphasis in both theory and practice on ex ante evaluation of legislation and evidence-based lawmaking. ${ }^{6} \mathrm{Ex}$ ante

dius \& A. Soeteman (eds.), Recht in geding // (Boom juridisch: Den Haag; 2016), at 15-25. W.J.M. Voermans, 'Waarom is er zo weinig wetgevingsonderwijs in de universitaire rechtenopleiding?', 30(2) RegelMaat (2015), at 68-80.

2. Seewww.academievoorwetgeving.nl. More in-depth: N.A. Florijn, 'De postinitiële masteropleiding tot wetgevingsjurist: opzet, resultaten en toekomst', 30 RegelMaat (2015), at 81-94.

3. See F. Leeuw, 'Empirical Legal Research: The Gap between Facts and Values and Legal Academic Training', 11(2) Utrecht Law Review (2015), at 19-33.

4. See E. Rubin, F. Uhlmann \& M. Bouwes, De opleiding van wetgevingsjuristen en wetgevingsonderzoekers in vergelijkend perspectief (Preadviezen Vereniging voor Wetgeving en Wetgevingsbeleid; 2011).

5. E. Page, 'Their Word is Law: Parliamentary Counsel and Creative Policy Analysis', (4) Public Law (2009), at 797.

6. M. Antokolskaia, 'Van politiek gestuurde wetgeving naar evidencebased wetgeving: Nog een lange weg te gaan'. in W. van Boom, I. Giesen \& A. Verheij (eds.), Capita Civilogie. Handboek Empirie en Privaatrecht (Boom Juridische uitgevers 2013), at 174 describes this move 
evaluation is a way to investigate whether the assumptions underlying a legislative draft are based on facts and empirical evidence that support the aims of the proposed bill. ${ }^{7}$ Unfortunately, many things can go wrong in this process. ${ }^{8}$

Cserne, for example, mentions the following: (1) epistemic concerns related to how empirical research is generated (e.g. validity issues but also concerns about what to do with inconclusive or contradictory research outcomes), (2) institutional features regarding how knowledge is channelled into the legislative process (e.g. how political opportunism may influence the interpretation of research outcomes) and (3) normative considerations related to counterfactual behaviour (e.g. decisions based on emotion or human instinct) and non-instrumental goals (e.g. symbolic features of laws and regulations). ${ }^{9}$ Moreover, as Rachlinski has rightfully stated, the whole idea of evidence-based law is highly controversial in itself because of the fact that the legislative process is controlled by different, often competing, rationalities. ${ }^{10}$

\section{Research Questions, Approach and Order of the Argument}

Empirical studies of important social phenomena often do not provide clear and unequivocal answers and laws may have conflicting purposes, which makes the relationship between policy problems, causes and remedies highly problematic. Moreover, outcomes of scientific

towards 'evidence-based legislation' as: 'the legislator in his choices for legislative interventions takes a rational and focused approach and does not let himself be guided by just political and ideological reasoning, but also by relevant results of scientific inquiry assessing the (expected) effectiveness of those interventions.' See also R. van Gestel, 'EvidenceBased Lawmaking and the Quality of Legislation: Regulatory Impact Assessments in the European Union and the Netherlands', in H. Schäffer and J. Iliopoulos-Strangas (eds.), State Modernization in Europe (Berliner Wissenschaftsverlag 2007) 141, who defines evidence-based legislation as: 'laws and policy initiatives are to be supported by research evidence and policies are preferably introduced on a trial and error basis. Implementation should only be considered on a larger scale after an evaluation of experiments or pilots have taken place.'

7. See J. Verschuuren (ed.), The Impact of Legislation: A Critical Analysis of Ex Ante Evaluation (Leiden/Boston; Brill; 2009) and more recently: S. Naundorf and C. Radaelli, 'Regulatory Evaluation Ex Ante and Ex Post: Best Practice, Guidance and Methods', in U. Karpen and H. Xanthaki (eds.), Legislation in Europe, Oxford: Hart publishing (2017), at 187-213.

8. See, e.g. N. Huls and N. Jungmann, 'Bedoelde en onbedoelde effecten van de Wsnp, in het bijzonder op crediteurengedrag', in W.H. van Boom, I. Giesen \& A.J. Verheij (eds.), Gedrag en privaatrecht (BJU: Den Haag 2008), at 487-503.

9. P. Cserne, 'Introduction: Legislation, Legal Episteme, and Empirical Knowledge', 1(3) The Theory and Practice of Legislation (December 2013), at 387-93.

10. J. Rachlinski, 'Evidence-Based Law', 96 Cornell L. Rev. 901 (2011). Important rationalities, apart from the scientific rationality, are the political, legal and social-economic rationality. See I. Snellen, 'Conciliation of Rationalities: The Essence of Public Administration', 24(2) Administrative Theory \& Praxis (2002), at 323-46. studies sometimes conflict with deeply held moral and political beliefs.

Regarding the latter, one just needs to think about psychological studies showing that people often do not act in their own best interest with regard to financial decisions, matters of healthcare or private safety, which is often seen as a reason for policymakers and legislators to nudge them into doing what is considered best for them. ${ }^{11}$ This approach associated with a politics of 'libertarian paternalism' conflicts with liberal views on 'personal autonomy' in which people are seen as responsible for their own actions even if these may sometimes be harmful for themselves (e.g. drinking, smoking, dangerous sports etc.). ${ }^{12} \mathrm{We}$ do not intend to take position in this debate but are interested in how different types of empirical research are used in the text and explanatory memoranda of proposals for new legislation when it comes to making normative choices, such as a duty to inform consumers, the granting of rights or a prohibition to conduct certain behaviour.

\subsection{Research Questions}

An interesting way to study the 'translation' from the empirical to the normative is to view legislative drafts through the lens of the proportionality principle, which is one of the principal standards for assessing the quality of legislation in the Netherlands. ${ }^{13}$ Proportionality review is part of the directives on legislative drafting, which require that proposals for new legislation are suited to accomplish the aims of the legislature, do not require more intrusive measures than strictly necessary to reach these aims and will not produce excessive burdens for particular addressees of the rules. ${ }^{14}$

The proportionality principle has two faces. It concerns the relationship between means and ends in law and policymaking (e.g. a certain policy measure suitable to accomplish a regulatory goal), but, it also contains normative considerations. Suppose, for example, that a proposed piece of legislation limits the rights and freedoms of certain citizens, which are protected by the Dutch constitution or the European Convention on Human Rights (ECHR), drafters will need to make sure that the intrusion on fundamental rights is both lawful and proportionate. If they do not succeed in doing so, there is a risk that courts will later on strike down this national piece of legislation because it conflicts with supranational law.

11. R. Thaler and C. Sunstein, Nudge: Improving Decisions about Health, Wealth, and Happiness (New Haven: Yale University Press, 2008).

12. C. Sunstein, Why Nudge: The Politics of Libertarian Paternalism (New Haven: Yale University Press 2014). See for an early critique: G. Mitchell, 'Libertarian Paternalism Is an Oxymoron'. 99(3) Northwestern University Law Review (2005), at 1245-1277, available at: https://ssrn. com/abstract $=615562$.

13. See A view on legislation, Parliamentary Papers II 190-1991, 22008, nr. 2, at 8. Directive 2.11 of the Directives on legislative drafting (digitally available at: http://wetten.overheid.nl/BWBR0005730/2018-01 -01). See also M.T. Bouwes, 'Het proportionaliteitsbeginsel in het wetgevingsbeleid', 28(3) RegelMaat (2013), at 148-65.

14. Criteria for proportionality review can be found throughout the Directives. See for instance 2.3, 2.5, 2.10 and 2.11. The directives can be found at: http://wetten.overheid.nl/BWBR0005730/2018-01-01. 
Important to know is that proportionality is not only used as a criterion for the ex ante evaluation of legislative drafts. ${ }^{15}$ It also functions as a standard for the ex post review of legislation by courts. ${ }^{16}$ It is needless to say that the possibility of judicial review of legislative interventions may give ex ante evaluation additional 'bite', especially in case the outcomes of the ex ante evaluation are sufficiently accurate to predict whether there are going to be proportionality issues in the future that will not be accepted by courts.

We have selected two legislative drafts in order to learn whether there might be a difference in how legislative drafters deal with (qualitative and quantitative) empirical research in justifying the proportionality of regulatory interventions. The first draft concerns a more policydriven technical (traffic) legislation, the second one a dossier concerning a (morally) sensitive topic, namely the protection of children in cases of intimate partner homicide by one of their parents. As we will explain more in-depth later, we realise that only two case studies do not justify bold conclusions, but that is also not our intention. We simply want to explore if the proportionality lens, which we will outline hereafter, ${ }^{17}$ could be a useful tool to analyse the way in which quantitative or qualitative empirical research is translated into normative legislative decisions.

Our study is also limited in the sense that we will restrict ourselves to the motivation about the use of empirical research provided in publicly accessible documents that can be found via the Dutch central legislative database. ${ }^{18}$ Special attention will be paid to the analysis of the legislative drafts by the Council of State as the principal advisor of the government on legislation, while also being the highest administrative court in the Netherlands. This dual role is interesting because in its judicial capacity, the Administrative Jurisdiction Division (AJD) of the Council of State also has to assess the proportionality of legislation ex post when a piece of legislation is challenged in an individual case against the government. ${ }^{19}$ The overarching question we will try to answer is:

To what extent is available empirical research used in explanatory memoranda of two different legislative drafts, namely the introduction of an alcohol lock programme in traffic law and the protection of chil-

15. See L.F.M. Verhey, 'Proportionaliteit als toetsingsmaatstaf', RegelMaat (2013-3), at 145-47.

16. See D. Harvey, 'Towards Process-Oriented Proportionality Review in the European Union', 23(1) European Public Law, (2017), at 93-121.

17. There is an enormous body of literature on the proportionality principle and proportionality review that we cannot discuss separately in this paper. See for a recent overview: V. Jackson and M. Tushnet (eds.), Proportionality: New Frontiers, New Challenges (Cambridge: Cambridge University Press; 2017).

18. Seewww.overheid.nl.

19. This is called 'exceptieve toetsing', which is a type of judicial review where administrative courts assess the underlying legislation in a procedure against an individual governmental decision (besluit) by way of assessment whether the piece of legislation runs against fundamental rights or legal principles. See, e.g. ABRvS 13 June 2017, ECLI:NL:RVS: 2017:1547 dren in cases of intimate partner homicide, in order to justify normative legal choices, viewed through the lens of the proportionality principle?

This main question will be divided into three sub-questions: (1) Is there a difference in how the results from qualitative and quantitative studies in the investigated cases play a role in the explanatory memoranda to justify normative choices, judged from a proportionality perspective? (2) Is there relevant empirical evidence missing in the explanatory memoranda or is the evidence not presented in a balanced manner and, if so, is this signalled in the ex ante evaluation of legislation by the Council of State as the organisation primarily responsible for the scrutiny of legislative drafts? (3) How could the possible neglect of (certain types of) empirical evidence be explained?

\subsection{Selection of Cases}

As already mentioned above, we are interested in possible differences between how quantitative empirical studies and qualitative sociolegal studies are used in legislative drafts from a proportionality perspective. In order to do this, we have selected two cases in which empirical studies were used to underpin and justify certain policy decisions by the legislature.

As a first case, we have looked for a problem of drunken driving, especially the legislation of the so-called 'Alcohol lock programme' (hereafter: alcolock). The advantage of a somewhat older case (2008) could be that it provides additional insight into the effectiveness of this legislative measure after enactment because there will probably be articles, reports and court cases available about this piece of legislation. At the same time, this is reason for caution because as researchers we should try to avoid hindsight bias and focus on what legislative drafters could and perhaps should have known at the time they wrote the draft.

The studies in the alcolock case are predominantly accident data and statistics that are predominantly quantitative in nature. Furthermore, this case represents a more classical instrumentalist type of traffic legislation where regulatory decisions are supposed to implement policies with regard to prevention of alcohol abuse by motorists. On the basis of what we know about how legislative drafters are educated and how the legislative process works, one would expect the qualitative research in this policy-driven legislative draft to be less visible and explicitly used to account for the normative choices being made. The main reason would be that draftsmen usually do not have a background in social science research methods, but are trained in law school in conducting doctrinal (textual interpretation) methods. ${ }^{20}$ As

20. K. Kraan and B. Niemeijer, 'De opleiding tot overheidsjurist', in M. Ahsmann et al. (eds.), Herijking van de juridische opleidingen (Preadviezen NJV, Deventer: Kluwer 2018), at 93-129. E.L. Rubin, R. Uhlmann \& M.T. Bouwes (eds.), De opleiding van wetgevingsjuristen en wetgevingsonderzoekers in vergelijkend perspectief, Preadviezen Vereniging voor Wetgeving en Wetgevingsbeleid (Nijmegen: Wolf Legal Publishers; 2011). 
Vick has argued, it is likely for (traditional) lawyers that information concerning alien disciplines or methods they are not familiar with cannot be transformed into knowledge compatible with the schemata they already possess. Therefore, Vick seems to believe that the closer the alien (empirical) information is to the type of research/data that lawyers are familiar with, the more likely it is going to be that this information will not be ignored. ${ }^{21}$ From this perspective, one would expect that quantitative empirical research stands little chance to be taken into account, even if the legislative draft itself concerns a rather policy-driven topic in which the dominant concern for both policymakers, legislative drafters and the wider public is going to be: will the alcolock serve its purpose?

The second case concerns a more recent (2016) niche topic at the intersection of criminal law and family law with a strong ethical and moral dimension, namely, the protection of children in cases of intimate partner homicide by one of their parents. This case is about the right to custody as well as how to deal with conflicts between different sides of the family about the placement of the children and regarding contact with the perpetrating parent in prison. The focus of the research on this problem is mostly qualitative. It concerns mainly sociolegal studies, based on interviews of persons involved in partner homicide as perpetrator, children of perpetrators or caregivers. From a moral perspective, this is a rather sensitive topic. Based on the assumption formulated by Vick that 'methodological closeness' is the determining factor with regard to how decisions made in the legislative draft (e.g. the voluntary or involuntary contact with the perpetrating parent) are justified by reference to empirical research, one would expect that the sociolegal research in this dossier will play a more prominent role than the quantitative empirical research in the alcolock case. The fact that the draft concerns a more sensitive topic should not really matter then.

The latter does not mean, though, there can be no alternative explanations for potential differences between the ways in which empirical research is used in the drafting of legislation in both cases. Because of this, and due to the fact that we were able to study no more than two legislative drafts more in-depth, we will also look into the literature on evaluation use after the analysis of our two legislative drafts. This will be done in order to see what possible other explanations might be available to clarify why empirical research has (not) been used in the drafts to support the proportionality of the legislative measures.

\subsection{Methodology: Looking through the Proportionality Lens}

The proportionality principle is a mechanism to scrutinise administrative or legislative measures. ${ }^{22}$ It is seen as 'a trade-off device which helps resolve conflicts between

21. D.W. Vick, 'Interdisciplinarity and the Discipline of Law', 31(2) Journal of Law \& Society (2004), at 189-90.

22. R. Gestel and J. de Poorter, 'Putting Evidence-Based Law Making to the Test: Judicial Review of Legislative Rationality', 4(2) The Theory and different norms, principles and values' ${ }^{23}$ A function of the proportionality principle is to guide the balancing of conflicting rights and interests. Stone Sweet and Mathews have operationalised the principle by identifying three analytical steps to balance facts and normative considerations, ${ }^{24}$ namely, (1) is a certain measure suitable to achieve the goal(s) set out by the legislature, (2) is it necessary in the sense that there are no less intrusive alternatives available to reach the policy goals and (3) are the costs not excessive in comparison with the benefits of the selected measure? ${ }^{25}$

We are not going to evaluate the two legislative drafts against the three just mentioned criteria ourselves. Instead we are going to study whether legislative drafters use empirical data to support the different elements of the proportionality review. In doing so, one has to realise that for the study of our two cases, the suitability question could never be answered with complete certainty anyway because as long as a legislative draft is not implemented, the real-life consequences are uncertain. However, what is possible is to study the assumptions underlying a proposed regulatory measure in order to see if these are based on solid data and reliable empirical evidence. If this is not the case, one cannot 'prove' that the measures will be ineffective, but it can be argued that a draft is most likely not going to have (all) the intended effects because the assumptions on which the draft is based are flawed.

In our analysis of the legislative files, we have focused on the references to empirical data and scientific research in the explanatory memorandum. Do the data and/or empirical studies actually support the factual assumptions and claims in the text of the draft and in the explanatory memorandum or is the interpretation perhaps one-sided or otherwise clearly inaccurate? We will also study whether the Council of State has looked into this and, if so, how the evidence was assessed. Moreover, via a literature search, we will double-check whether there are relevant studies that have not been mentioned in the explanatory memorandum but could have shed a different light on the topic. We used keywords (e.g. alcohol lock, alcolock, alcoholslot and (intimate) partner homicide, partner murder, partner violence etc.) to search databases, such as WorldCat, KluwerNavigator, HeinOnline, Westlaw, Google Scholar) to look for studies that were not mentioned in the drafts. The idea is to find out whether easily accessible and relevant studies may have been (deliberately) overlooked or ignored by the drafters. Such behaviour could be a sign that other, more strategic, considerations impact the use of empirical research.

Practice of Legislation (2016), at 155-85, doi:10.1080/205088 40.2016.1259899.

23. T. Harbo, 'The Function of the Proportionality Principle in EU Law', 16(2) European Law Journal (2010), 158-85, at 165.

24. See for instance A. Stone Sweet and J. Mathews, 'Proportionality Balancing and Global Constitutionalism', 47 Columbia Journal of Transnational Law (2008), at 73-164.

25. See for instance J. Jans, 'Proportionality Revisited', 27(3) Legal Issues of Economic Integration (2000), at 239-65. 
Next, we will move to the necessity of the regulatory measures and how these are accounted for. Assessing the necessity of proposed regulatory instruments always requires some kind of study of possible alternative measures that could be used to reach the same goals. If there is a choice between several in principle equally suitable and effective measures, the proportionality principle requires that the least onerous one should be selected. ${ }^{26}$ This presupposes a regulatory impact assessment in which alternative measures have been studied. Does the explanatory memorandum explicitly refer to an impact assessment or to any other (empirical) method of ex ante evaluation in which alternatives have been studied? If not, does the Council of State signal this? In case the Council does not, is that even noticed by the House of Representatives?

The last step is to analyse whether effects of a draft are not excessive in relation to the interests affected. As Andenas and Zleptnig have argued, it is here where a true weighing of competing objectives takes place. The more intense the restrictions or the higher the costs for a particular interest, the more important the justification for the countervailing interest and benefits needs to be. ${ }^{27}$ This last test is undoubtedly the most controversial one. ${ }^{28}$ The objective is to examine whether the severity of the harm to the individual, and the reasons of general interest justifying it, are reasonably proportional to each other. ${ }^{29}$ There is no objective yardstick to weigh these different interests, which is why this test is so often criticised. We are not going into that here, though, because our intention is merely to study whether and how empirical research has played a role in the balancing of costs and benefits as accounted for in the explanatory memorandum. Is there, in other words, an explicit reference to how costs and benefits are weighed and is there a reference to empirical data of scientific (e.g. economic) research here? It is not up to us to decide whether a fair balance has actually been struck between costs and benefits. What we like to learn is if legislative drafters support cost-benefit analysis with empirical data.

26. This requirement can also be found in Art. 7 of the Dutch guidelines for legislative drafting, which states: 'Before deciding to introduce a regulation, the following steps shall be taken: a. knowledge of the relevant facts and circumstances shall be acquired; $b$. the objectives being aimed at shall be defined in the most specific, accurate terms possible; $c$. it shall be investigated whether the objectives selected can be achieved using the capacity for self-regulation in the sector or sectors concerned or whether government intervention is required; $d$. if government intervention is necessary, it shall be investigated whether the objectives in view could be achieved by amending or making better use of existing instruments, or, if this proves impossible, what other options are available; e. the various options shall be compared and considered with care.'

27. M. Andenas and S. Zleptnig, 'Proportionality and Balancing in WTO Law: A Comparative Perspective', 20(1) Cambridge Review of International Affairs (2007), 71-92, at 76.

28. L. Tremblay, 'An Egalitarian Defense of Proportionality-Based Balancing', 12 (4) International Journal of Constitutional Law (2014), 864-90 at 865 .

29. A. Barak, 'Proportional Effect: The Israeli Experience', 57(2) University of Toronto Law Review (Spring 2007), 369-82, at 374.
The interesting thing about the proportionality test is that it requires rational legal arguments in the decisionmaking process. As Craig has rightfully claimed, those arguments need to be justified in a public deliberative process. ${ }^{30}$ Our intention is to show to what extent this actually happens during the preparation of our legislative drafts.

\section{Analysis of the Cases}

Regarding both cases, we will start with an introduction of the legislative proposal and a short overview of the relevant studies. After that, we investigate to what extent the studies played a role with regard to the different elements of the proportionality test. We conclude each case study with a brief conclusion of our findings.

\subsection{The Alcohol Lock Case}

In 2008, the Dutch government presented a legislative draft to amend the Road Traffic Act (RTA) 1994 in order to introduce a so-called 'alcohol lock programme'. ${ }^{31}$ This was meant to reduce the number of victims of road accidents due to drunken driving. The annual number of road deaths in this period was 800 and a case-control study in the police district of Tilburg concluded that at least $25 \%$ of these fatalities were caused by alcohol use. ${ }^{32}$ This would result in at least 200 casualties a year. Seventy-five per cent of the victims are the result of drunken drivers with a blood alcohol content $(\mathrm{BAC})$ of $1.3 \mathrm{~g} / 1$ or more. Studies by the Ministry of Transport, Public Works and Water Management revealed that, although the number of offences is slowly decreasing, this is not the case for the category of heavy drinkers who are caught with a BAC of $1.3 \mathrm{~g} / 1$ or more. ${ }^{33}$ Moreover, the minister concludes from accident statistics that existing measures to reduce the use of alcohol in traffic, such as media campaigns and education programmes, have had limited effect on this category of drivers. ${ }^{34}$

The draft to amend the RTA 1994 argues that new measures to prevent alcohol abuse are necessary and that the introduction of an 'alcolock' (breath alcohol ignition interlock) would be an appropriate tool to make heavy drinkers learn how to separate the use of alcohol from driving a motor vehicle. ${ }^{35}$ The idea is to amend the existing procedure for driving license suspension and mandatory educational measures for offenders focused

30. P. Craig, 'Unreasonableness and Proportionality in UK Law', in E. Ellis (ed.), The Principle of Proportionality in the Laws of Europe (Oxford: Hart 1999), 85-106, at 99-100. See also P. Craig, 'The Nature of Unreasonableness Review', 66 Current Legal Problems (2013), at 131-67.

31. Parliamentary Papers II 2008-2009 31896 nr. 2

32. M. Mathijssen and S. Houwing, The Prevalence and Relative Risk of Drink and Drug Driving in the Netherlands: A Case-Control Study in the Tilburg Police District (Leidschendam: SWOV Institute for Road Safety Research, R-2005-9).

33. Parliamentary Papers II 2008-2009, 31 896, nr. 3, at 7 .

34. Ibid., at 8.

35. Ibid., at 8 . 
on the use of alcohol in traffic with the possibility to participate in the alcolock programme at one's own expense. When people are selected to participate in the programme, their car will be equipped with the alcolock, which prevents ignition of the engine. Every time the driver wants to start the car, he is submitted to a breath test. In case the BAC is too high, the engine will not start. Even while driving, the alcolock requires random retests. This is to prevent the person from being drunk while driving and to avoid that another person takes the breath test before starting the car. The period of being sentenced to have your car equipped with a lock is in principle two years. In case someone sabotages the alcohol lock or gets round it by driving in another car, this period will be lengthened, the driving license will be declared invalid or in the worst case, someone must go to jail. The alcolock is used to enable drivers to prove they are no longer alcohol-dependent when participating in traffic.

Technically, the alcolock is equipped with a recorder. Every breath test is recorded and can be read out by a counsellor attributed to the programme. On a regular basis, the counsellor and the convicted person meet each other to discuss the results of the breathalyser in order to see if additional measures are necessary.

\subsubsection{Empirical Research}

The explanatory memorandum of the legislative draft enabling the introduction of the alcolock programme refers to various empirical studies in the United States, Canada and Sweden since 1997. ${ }^{36}$ These would show that drivers who participate in the programme on average reoffend $80 \%$ less often than drivers with temporary suspensions of their license. The drafters in particular refer to a study by Beirness and Robertson, ${ }^{37}$ concluding that a number of conditions must be fulfilled to make the programme effective. There should be: an obligation in the sense that drivers may only use their vehicles if an alcolock is installed; a code on the driving license is nec-

36. M. Weinrath, 'The Ignition Interlock Program for Drunk Drivers: A Multivariate Test, 43(1) Crime Delinq. (1997), at 42-59. R. Voas and A.S. Tippetts, 'Requiring Interlocks for Reinstatement: The Florida Example'. Paper Presented at the 7th Annual International Ignition Interlock Symposium, Bachelor Gulch, Colorado, October 22-24 (1997). K. Beck, W. Rauch, E. Baker \& A. Williams, 'Effects of Ignition Interlock License Restrictions on Driver on Multiple Alcohol Offences: A Random Trial in Maryland', 89 American Journal of Public Health (1999), at 1696-1700. R. Voas, P. Marques, A. Tippetts \& D. Beirness, 'The Alberta Interlock Program: The Evaluation of a Province-Wide Program on DUI Recidivism', 94(12) Addiction (1999), at 1849-1859, L. Venzina, 'The Quebec Alcohol Interlock Program: Impact on Recidivism and Crashes', in D.R. Mayhew and C. Dussault (eds.), Alcohol, Drugs and Traffic Safety 0 T2002. Proceedings of the 16th International Conference on Alcohol, Drugs and Traffic Safety. Montreal, August 4-9, 2002 (Quebec City: Societé de I'assurance automobile du Quebec; 2002), 97-104. B. Bjerre, 'Primary and Secondary Prevention of Drinking and Driving by the Use of Alcolock Device and Program: The Swedish Experience', in P. Marques (ed.), Alcohol Ignition Interlock Devices. Volume II 2005: Research, Policy, and Program Status (Oosterhout, the Netherlands: International Council on Alcohol, Drugs, and Traffic Safety (ICADTS), 2005). J. Frank, R. Raub, R. Lucke \& W. Wark, 'Illinois Ignition Interlock Evaluation', in Proceedings of the 16th International Conference on Alcohol, Drugs and Traffic Safety (2002), at 105-9.

37. Parliamentary Papers II 2008-2009, 31 896, nr. 3, at 9. essary to inform the police about participation in the programme during routine inspections; the obligation to take part in the programme should be based on administrative law instead of criminal law; there needs to be compliance-monitoring by reading out the data from the breathalyser registration unit and a regular inspection of the alcolock to detect attempts of fraud; the programme needs to be flexible in the sense that the duration can be adjusted to the individual behaviour of the participants in the programme on the basis of the data from the registration unit.

Based on a study by SWOV ${ }^{38}$ counting on an annual participation rate of between 2,000 and 6,750 persons and a maximum number of participants of 13,500 after two years, it was estimated that introduction of the alcolock should lead to an annual reduction of between twenty-five and thirty road deaths and a decrease in the number of people who have to be hospitalised of between 250 and 300. This estimation was based on the following assumptions: a two-year programme; participation in the programme as soon as possible after the offence; regular monitoring of the data from the registration unit; extension of the alcolock programme (each time for six months) in case offenders have shown to be unable to separate the use of alcohol while driving; no direct participation in the programme for offenders with a BAC above $2.1 \mathrm{~g} / 1$ (experienced drivers) and $1.8 \mathrm{~g} / 1$ (starting drivers).

Regarding the latter, the explanatory memorandum points to several studies showing that an alcolock programme could also be successful for the latter group of heavy drinkers, ${ }^{39}$ but the people in this category should first undergo a test whether they are fit to follow the programme. As far as the practical functioning of the alcolock is concerned (e.g. can it be installed in all cars, does the retest not pose dangers when conducted during driving? etc.), the drafters point to a pilot project in which eighty persons tested two different alcolocks during a period of eleven weeks. ${ }^{40}$ This pilot showed no practical difficulties in the daily use of the alcolock. The draft also point to studies showing that once the alcolock is removed from a car, there are hardly any positive effects anymore on the alcohol use. That is why a period of at least two years is recommended for participation in the programme. ${ }^{41}$ A longer period is believed to have more durable results on the driving behaviour of offenders. Moreover, reference is made to foreign studies showing that the introduction of an alcolock works better in case it is accompanied by a counselling and guidance programme. ${ }^{42}$ This is why the draft introduces a

38. SWOV institute for road safety research, Geschat effect op de verkeersveiligheid van een alcoholslotprogramma (ASP) en de kosten-batenverhouding ervan, Leidschendam, 2009

39. Parliamentary Papers II 2008-2009, 31 896, nr. 3, at 13.

40. Seehttps://www.rijksoverheid.nl/binaries/rijksoverheid/documenten/ rapporten/2008/10/01/demo-alcoholslot-onderzoeksresultaten/demoalcoholslot-onderzoeksresultaten.pdf.

41. Parliamentary Papers II, 2008-2009, 31 896, nr. 3, at 54.

42. P. Marques, A. Tippets, R. Voas, E. Danseco \& D. Beirness, 'Predicting DUI Offenses with the Alcohol Interlock Recorder', 33 Accident Analysis and Prevention (2001), at 609-19; P. Marques, R. Voas \& 
parallel programme focused on the motivation and learning of participants, which should not be seen as an addiction treatment and rehabilitation programme though, because the programme is not set up to 'cure' alcoholics but to teach regular (non-addicted) drivers to separate the use of alcohol from participating in traffic. ${ }^{43}$

\subsubsection{Aims of the Draft}

The first thing to be noticed in the draft is that the text of the explanatory memorandum is rather vague on what are the exact goals of the alcolock programme. The proposal presents specific targets in terms of an estimated decrease in the number of (fatal) casualties, but the empirical evidence on how these targets are going to be accomplished is rather weak. Problematic is also the lack of clarity on the relationship between the introduction of alcolock programmes in other legal systems and the estimated drop in (fatal) accidents in the Netherlands. Of course one could argue that the best possible 'proof' of the real-life effects of alcolock programmes can be found by looking at countries where there is experience with these systems. However, the problem is that very little information is provided with regard to the context in which these programmes functioned abroad and there is also no information about the longitudinal effects. This makes it highly problematic to extrapolate the findings abroad to the Dutch situation.

\subsubsection{Suitability}

Striking is that the explanatory memorandum leans

heavily on evaluation studies and pilot projects in other countries; most notably the United States, Canada, Australia and Sweden, but the regulatory context in these countries might very well be quite different from the one in the Netherlands. Remarkable is, therefore, that a 1994 SWOV study, which is not mentioned in the explanatory memorandum, concluded that

it would be of benefit to conduct an experiment with alcohol locks in the Netherlands. Sufficient knowledge is available to set up a sound experiment, linked to an effectivity study. Such an experiment would only be useful, however, if the user is also subjected to intensive supervision. ${ }^{44}$

Such a study has never been undertaken, though. The aforementioned pilot project was not set up as a study to measure the effectiveness of the programme, but merely served to detect potential practical and technical prob-

D. Timken, ‘Preliminary Outcomes from a Texas Manual-Based Group Motivational Intervention Supplement for Court-Stipulated Interlock DUI Offenders', in Proceedings of the 17th International Conference on Alcohol, Drugs and Traffic Safety (2004). G.P. Marques, R. Voas, S. Tippetts, K. Blackman, D. Timken \& C. Field, 'Motivational Intervention Keyed to Interlock Use Reduces the Rate of Positive BAC Tests', in B. Logan, D. Isenschmid, J. Walsh, D. Beirness \& J. Morland (eds.), Proceedings of the T2007 Joint International Meeting of TIAFT/ICADTS/ IIS, August 26-30, Seattle (WA: ICADTS; 2007).

43. Parliamentary Papers II, 2008-2009, 31 896, nr. 3, at 27-30.

44. J. van der Sluis, 'Alcoholslot Onderzoek naar de ervaringen in het buitenland en de mogelijkheden in Nederland Leidschendam' (Stichting Wetenschappelijk Onderzoek Verkeersveiligheid SWOV, 1994), at 4. lems in the implementation of alcolocks. From a methodological perspective, only a well-designed experiment could deliver solid evidence about the effectiveness of such a programme in the Netherlands.

The Council of State also pointed to weaknesses in the programme due to (1) the lack of a parallel mandatory addiction treatment programme aimed to take away the root cause of the problems of the group of heavy drinkers on which the alcolock programme is focused; (2) the susceptibility to fraud of the programme, shown for example by the refusal to introduce additional sobriety inspections (e.g. think of people with an alcolock notification on their driving license who might keep driving with borrowed cars); (3) potential overlap with criminal law measures, which can make that offenders cannot be submitted to the alcolock programme due to, among other things, the need to avoid ne bis in idem problems. This not only delays the implementation of the programme, but could also increase the uncertainty among drunken drivers about what lies in wait for them and affect the willingness to participate. ${ }^{45}$ The government does not respond by referring to other research in the follow-up to the advice by the Council of State.

The debate of the draft in parliament did not really raise new issues with regard to the suitability of the programme and the research conducted in that respect with one important exception. Serious worries were cast concerning the advice by the Dutch Association of Psychiatrists with respect to the dangers of allowing alcoholics (addicts) to enter into the programme without a mandatory rehab programme. Initially, the government had ignored this advice, but in reaction to questions in parliament about this, an elaborate response was given referring to a wide list of foreign studies with respect to the consequences of allowing alcoholics into alcolock programmes. The government concludes on the basis of evaluation of foreign programmes and studies that these programmes would not be less effective for people with an alcohol addiction. ${ }^{46}$

\subsubsection{Necessity}

Although the draft underlines the fact that alternative policy measures, such as information campaigns (e.g. the 'Bob campaign' focusing on the responsibility of sober drivers taking friends for a night out), education programmes and regular sobriety inspections have not delivered the desired results, ${ }^{47}$ no impact assessment seems to have been conducted. This means that a systematic comparison between potential alternative policy measures, such as mandatory medical treatment and targeted rehab programmes, is lacking. ${ }^{48}$

As far as comparative studies are concerned, these concentrate on experiences with alcolocks in other countries and do not include other policy alternatives. Hence, it is

\footnotetext{
45. Parliamentary Papers II 2008-2009, 31896 , nr. 4, at 4-7.

46. Parliamentary Papers II 2009-2010, 31 896, nr. 7, at 4

Ibid., at 8.

48. According to $\S 4.43$ (b) of the directive on legislative drafting, the explanatory memorandum should provide an overview of how alternatives to legislation have been taken into account.
} 
no wonder that alcolock programmes come out on top. The statement in the explanatory memorandum that no other measures abroad can be found with a similar effect to the alcolock, therefore, sounds rather pretentious. ${ }^{49}$ After all, one cannot know whether less intrusive and equally effective measures are available, unless a systematic study of potential alternatives is undertaken.

Additionally, there is hardly any mentioning in the draft about the methodological strengths and weaknesses of the existing studies in this field. ${ }^{50}$ This makes it difficult to rate the outcomes of the available foreign studies concerning the effectiveness of alcolock programmes.

The Council of State does not really discuss the lack of serious attention for alternatives to the alcolock programme and/or the strengths and weaknesses of the studies mentioned in the explanatory memorandum. In parliament, this is also not a serious issue. Both State Councillors and Members of Parliament (MPs) seem to depend quite heavily on the information provided by the government in the draft and did not carry out independent research on their own nor do they point to the lack of attention for potential alternatives to the alcolock instrument because they seem focused on the single policy instrument the draft presents. This is also the only instrument supported by (empirical) data and research.

\subsubsection{Proportionality stricto sensu}

In terms of 'costs and benefits', the draft mentions an estimated decrease in the number of road deaths and serious injuries, depending on the number of participants and the time between driving license suspension or revocation and active participation in the programme. It also predicts the costs for individual participants in the programme to get the alcolock installed. These costs would lie somewhere between 1,300 and 2,000. The draft also mentions that the exact costs are hard to predict because of the fact that the alcolock programme represents 'work in progress'. Costs would depend on competition between the suppliers of alcolock devices, the number of alcolocks that are going to receive a certificate from the Central Bureau for Driving Licenses and the number of participants in the programme. What the draft makes clear, though, is that all costs for the certification and installation of the alcolock, the maintenance of the registration system, the monitoring of the results from alcolock registration unit and the cost for a driving license with an alcolock notification need to be covered by the participants. ${ }^{51}$

The Council of State warned that the participation in the programme might prove to be disappointingly low because of the costs involved in participating. After the introduction of the alcolock in 2011, however, the costs

49. Parliamentary Papers II 2008-2009, 31 896, nr. 3, at 9 .

50. At the European Union level, this is somewhat different because services of the European Commission are instructed to explain the methodological strengths of evaluations as soon as external evaluations are transferred to Staff working documents. See European Commission, Better Regulation Toolbox (2015), at 364-74. For an example, Seehttps://ec.europa.eu/food/sites/food/files/gfl_fitc_comm_staff_ work_doc_2018_part1_en.pdf, at 23.

51. Ibid., at 30 for participating appeared to be much higher than the estimated maximum of 2,000. On average, the costs turned out to be around 5,000. This meant that many offenders were not financially capable of participating because of the costs. Consequently, their driving license was suspended for five years because the 'voluntary' alternative of participation in the alcolock programme was de facto unfeasible. In 2015, the AJD of the Council of State declared the regulation on which the 'educational measure' of the alcolock was based unlawful because it violates the proportionality principle enshrined in Article 3:4 of the General Administrative Law Act. ${ }^{52}$

The AJD argued that the regulation did not take the personal situation of different drivers and their dependence on a driving license sufficiently into account. The possibility for people to continue driving under the realm of a special license linked to an alcolock programme with reasonable costs had been a cornerstone of the amendments to the Road Traffic Act 1994, but there was no serious alternative to maintain a limited driving license without partaking in the alcolock programme. Apart from that, the AJD revealed that in the meantime, numerous cases had been brought before it in which the defendants claimed that participation in the programme was financially impossible. Some offenders did not own a car and were caught driving a borrowed or rental car. In case offenders cannot participate purely because of the height of the costs, the AJD found that the educational measure on which the alcolock rests fails to take the personal circumstances of offenders, who sometimes rely on a driving license for their job (e.g. taxi drivers and car mechanics), into account. This leads to a violation of the proportionality principle.

Last but not least, the AJD noticed that participating in an alcolock coincided with the possibility of imposing criminal sanctions on drunken drivers, which the Supreme Court had deemed problematic in light of Article 6 ECHR. ${ }^{53}$ On both accounts (costs and benefits and criminal sanctions), the government responded in its additional report. Regarding the possibility of concurrence of sanctions, the government refers to the public prosecutor service and the judiciary without answering to the arguments of the AJD. With respect to the cost and benefits, the government mainly stresses that the costs are reasonable, considering the fact that entering into the programme allows offenders to continue to drive an automobile, which would otherwise be impossible. In the parliamentary debate, one mainly sees a repetition of arguments already brought forward by the Council of State and a reminder that the government should strive to keep the costs of the programme for participants as low as possible.

\subsubsection{Intermediary Conclusion}

We may conclude that on all three accounts of proportionality (suitability, necessity and costs and benefits), 


\begin{tabular}{|c|c|c|c|}
\hline & Explanatory memorandum & Council of State & House of Representatives \\
\hline Empirical research & $\begin{array}{l}\text { Several (foreign) studies most- } \\
\text { ly about the positive experi- } \\
\text { ence with alcolocks }\end{array}$ & $\begin{array}{l}\text { Referring to studies mentioned } \\
\text { in explanatory memorandum. } \\
\text { No other evidence }\end{array}$ & $\begin{array}{l}\text { Referring to study mentioned } \\
\text { in explanatory memorandum. } \\
\text { No other evidence }\end{array}$ \\
\hline Suitability & $\begin{array}{l}\text { Abstract goals Only foreign } \\
\text { studies about effects but } \\
\text { national study that advises to } \\
\text { conduct an experiment ig- } \\
\text { nored }\end{array}$ & $\begin{array}{l}\text { Mentioned studies not entirely } \\
\text { convincing about suitability: } \\
\text { (1) lack of a parallel mandato- } \\
\text { ry addiction treatment (2) risk } \\
\text { of fraud and (3) concurrence } \\
\text { with criminal sanctions }\end{array}$ & $\begin{array}{l}\text { Repetition of arguments by the } \\
\text { Council of State, but extra con- } \\
\text { cern regarding addicted per- } \\
\text { sons }\end{array}$ \\
\hline Necessity & $\begin{array}{l}\text { No comparison of regulatory } \\
\text { alternatives: unsupported } \\
\text { claim that there are no rele- } \\
\text { vant alternatives }\end{array}$ & No attention for alternatives & No attention for alternatives \\
\hline Proportionality stricto sensu & $\begin{array}{l}\text { Costs are hard to predict } \\
\text { because of the fact that the } \\
\text { alcolock programme repre- } \\
\text { sents 'work in progress'. Costs } \\
\text { depend on competition } \\
\text { between the suppliers of alco- } \\
\text { lock devices and the benefits } \\
\text { are difficult to express in mon- } \\
\text { etary terms }\end{array}$ & $\begin{array}{l}\text { Serious doubts about costs due } \\
\text { to participation rate. Also con- } \\
\text { cerns about concurrence with } \\
\text { criminal sanctions not taken } \\
\text { into account }\end{array}$ & $\begin{array}{l}\text { Repetition of arguments made } \\
\text { by Council of State and } \\
\text { emphasis on the importance of } \\
\text { keeping costs as low as possi- } \\
\text { ble }\end{array}$ \\
\hline
\end{tabular}

the draft had serious shortcomings. The effectiveness of the programme was based solely on foreign experiences, but was not actually tested via an experiment as recommended by SWOV; there has been no systematic study of possible alternatives to an alcolock programme; the balancing of costs and benefits for participating in the programme appears to be built on quicksand for which the Advisory Division of the Council of State had warned prior to the bill being enacted, which turned out to be pretty accurate in light of the case law of the AJD of the same Council of State that followed upon the implementation of the bill that introduced the alcolock.

\subsection{The Case of the Right to Contact after Partner Homicide}

In the Netherlands, every year on average 26 children lose one of their parents because of intimate partner homicide. Regulating the right of contact after parental intimate partner homicide, the draft of 2016 concerning the right to contact after partner homicide introduces a mandatory procedure according to which decisions about contact between the children and the perpetrating parent need to be made by a Juvenile court. These decisions should be based on a request made by the Council for Child Protection. ${ }^{54}$
This Council for Child Protection is responsible for assessing the personal circumstances of children who lost one of their parents (usually the mother) because of homicide by the other parent. The council is free to obtain the children's opinion to estimate whether contact with the perpetrating parent is in their best interest. No sooner than two years after the court's decision the parent is allowed to object to a negative decision from the Juvenile court. The reason for this two-year 'cooling down' period is to give children time to recover from their (expected) traumatic experience. Moreover, the idea is to keep children as much as possible out of the conflicts between the families of the victim and the perpetrating parent. The Juvenile court usually gives custody to a certified youth care facility.

According to the draft, reducing stress and protecting the well-being of the children are the main reasons for the introduction of the new procedure. ${ }^{55}$ Limiting contact with and access to the children is a restriction of the (remaining) parent's right to family life as protected by Article 8 of the ECHR. In the explanatory memorandum to the draft, the government considers this restriction to be a legitimate exception, which is lawful and necessary in accordance with Article 8(2). ${ }^{56}$ 


\subsubsection{Empirical Research}

The study 'Care for children after intimate partner homicide' from the Psychotrauma Centre of Utrecht University's Wilhelmina Children's Hospital, ${ }^{57}$ mentioned in the explanatory memorandum, ${ }^{58}$ shows the impact that partner homicide has on children, especially in case they witnessed the crime. Although their grief symptoms are relatively moderate compared with children in a control group who have also lost a loved one in another situation than partner homicide, more than half of the children experience posttraumatic stress syndromes. ${ }^{59}$

Nearly all children mentioned in the study received professional assistance and most of them had some kind of contact with the perpetrating parent in detention. Only in a few cases there has been some pressure from the perpetrator or from his family, but in the vast majority of the cases, the will of the child concerning (no) contact has been followed. According to the conclusions of the Utrecht University study, each placement option may work well and a (provisional) guardianship can provide the opportunity to assess and plan what is in the best interest of the child. Children should, however, not be forced into having contact with the perpetrating parent, nor should they be denied contact if such contact is desired and reasonably possible. Providing stability and safety of their situation is of great importance to the children. ${ }^{60}$

It is remarkable that the explanatory memorandum leans so heavily on the single study mentioned above, although there were other studies available at the time. ${ }^{61}$ One of these studies, which compares data from ten different European Countries, ${ }^{62}$ claims there is a need for reliable and comparable statistical data across countries in order to better understand the phenomenon of intimate partner homicide and to enable more effective policymaking improving the well-being of children, public

57. E. Alisic et al., Zorg voor Kinderen na Partnerdoding; onderzoek in opdracht van het WODC (Utrecht: Universitair Medisch Centrum; 2014).

58. Parliamentary Papers II 2015-2016, 34 518, nr. 3, at 2

59. Alisic et al. (2014), above n. 57, at 7 .

60. Ibid., at 100-1.

61. See L. Lewandowski et al., "“He Killed My Mommy!" Murder or Attempted Murder of a Child's Mother', 19(4) Journal of Family Violence (2004), 211-20; T. Wortham, 'Intimate Partner Violence: Building Resilience with Families and Children', 23(2) Reclaiming Children and Youth (2014), at 58-61; J. Hardesty et al., 'How Children and their Caregivers Adjust after Intimate Partner Femicide', 29(1) Journal of Family Issues (2008), at 100-24. E. Spencer-Carver, Social Support for Children Who Had a Parent Killed by Intimate Partner Violence: Interviews with Mental Health Workers (Manhattan (Kansas): State University; 2008). This last study, by the way, mentions that the outcomes of the studies may very well depend quite heavily on the chosen perspective. From a feminist theory perspective, the contact between the perpetrating father and his children would probably meet with far more scepticism than in case the same matter would be studied from the perspective of the resiliency theory.

62. C. Corradi and H. Stöckl, 'Intimate Partner Homicide in 10 European Countries: Statistical Data and Policy Development in a Cross-National Perspective', 11(5) European Journal of Criminology (2014), at 601-18. health and welfare reform. ${ }^{63}$ This seems to suggest a lack of reliable data at present, which raises questions about the strength of the evidence base of the proposed draft.

\subsubsection{Aims of the Draft}

According to the explanatory memorandum,${ }^{64}$ the main aim of the draft is to have as much stability and peace of mind for children involved in intimate partner homicide as possible. This does not sound as a very clear objective because what counts as 'peace and stability' leaves much room for interpretation. A second aim is to prevent 'forced contact' between children and their perpetrating parent. So far, there is no mandatory procedure for the decision about the visiting rights of the parent, which runs the risk of making children a pawn in the game of passing the buck between the families of the victim and the perpetrator.

Although the aims are mentioned by the Utrecht University study, there is no empirical evidence showing the relation between the new procedure in which a Juvenile court decides about the visiting arrangements and the well-being of the children. In other words, this procedure is not the outcome of the study and is no part of the conclusions either. In the current procedure, contact between children and their convicted parent is possible without a court decision. According to the explanatory memorandum, this is considered unsatisfactory in practice. ${ }^{65}$ However, this is not an outcome of the Utrecht University study. Moreover, the latter study reveals that in $94 \%$ of the cases the will of the children (not) to visit the perpetrating parent is already respected. This begs the question: Why is new legislation required?

\subsubsection{Suitability}

Whether the new procedure will be an effective remedy advancing the children's mental stability and security has not been explained in the Utrecht University study nor in the explanatory memorandum. Actually, this study only proves the contact between the children and the perpetrating parent to be problematic. In the parliamentary debate, spokesmen of the political parties call this study, requested by parliament, important and valuable without explaining why. ${ }^{66}$ The Council of State is sceptical here because the Council for Child Protection already adheres to a protocol according to which the court that decides over custody may take into account the visiting rights and the interest of the children. According to the Council of State, there is no reason to believe that the advice by the Council for Child Protection is not taken seriously. ${ }^{67}$

May one reasonably expect the new procedure, according to which there ought to be a court decision in every case, to reduce the number of cases in which there is

\footnotetext{
63. Ibid., at 615. See also F. Koenraadt and M. Liem, 'Fataal huiselijk geweld: Doding van eigen kind, partner of ouder, Justitiële verkenningen', 36(8) Justitiële verkenningen (2010), at 100-14.

64. Parliamentary Papers II 2015-2016, 34 518, nr. 3, at 4

65. Parliamentary Papers II 2015-2016, 34 518, nr. 3, at 4

66. Parliamentary Proceedings II, at 73-3-3 and 73-3-5.

67. Parliamentary Papers II 2015-2016, 34 518, nr. 4, at 3
} 
contact with the perpetrating parent against the children's will? This is doubtful. Firstly, because there are only a few cases found in the study in which there was contact against the will of the children. Secondly, where there was forced contact, this usually was the consequence of a court order! In other words, from the perspective of avoiding involuntary contact between the perpetrating parent and the children, leaving the decision to courts seems to be counter-intuitive. It is far from self-evident to see courts as the most suitable decision makers in these kinds of cases if respect for the free will of children is the main aim of the legislature. Apart from that, going through a court procedure as such may also have traumatic consequences for the children. ${ }^{68}$ The proposers (MPs) did not respond to the Council of State's judgement that the research findings could not be seen as evidence to support this legislative initiative. ${ }^{69}$

The proposed legislation appears to be based on the assumption that the only reason for the homicide has been the perpetrating parent's intention to kill his partner. In his study about partner homicide, however, De Boer described many possible motives the perpetrator parent might have had to commit homicide. ${ }^{70}$ In the advice of the Association of Family Law and Divorce Mediators, the question was raised whether the new procedure would be suitable in cases where the perpetrator's intent has been to defend the child against the other parent. ${ }^{71}$ This raises doubt about the stereotype of the perpetrating parent found in the legislative draft. More importantly, though, there is no evidence that the new procedure will lead to more peace and stability and less forced contacts between children and the perpetrating parent.

\subsubsection{Necessity}

Could we ascertain the proposed procedure to be the least intrusive measure reaching the aims of the bill? In the Utrecht University study, no comparison has been made between alternative modes of regulation. Likewise, the explanatory memorandum did not refer to any study of alternatives, although, according to Section 2.3 of the Directives on legislative drafting, such a study is mandatory.

In the course of the legislative process, some alternatives are mentioned, such as a procedure according to which only the scrutiny of the Council of child protection would be mandatory, but the consequences of such options have not been studied. ${ }^{72}$ Hence, we do not know

68. Alisic et al. (2014), above n. 57, at 101.

69. Parliamentary Papers II 2015-2016, 34 518, nr. 4, at 3 .

70. A.P. de Boer, Partnerdoding. Een empirisch forensisch-psychiatrisch onderzoek; proefschrift Katholieke Universiteit Nijmegen (Arnhem: Gouda Quint BV; 1990). In this study, De Boer examines 104 male and 20 female spouse killers who were submitted to a psychiatric examination. In 122 of the 124 cases, the psychiatrists concluded that, at the time of the deed, there was a defective development and/or impairment of the offender's mind.

71. By letter of January 12. 2015, published in: Parliamentary Papers II 2012/2013, 33 552, nr. 3.

72. This lighter alternative was mentioned in the Council of State's advice. whether lighter alternatives to decision-making by a Juvenile court would suffice to accomplish the aims of proposed legislation.

In the initial draft, avoiding communication between children and the perpetrating parent for at least two years was meant to be the rule. The idea was that courts would only decide to allow contact under exceptional circumstances. This 'no contact, unless ...' was altered because of the advice of the Council of State. The core of the council's advice is to respect the balance between caring for the child's well-being on the one hand and respecting the parent's rights to contact on the other. ${ }^{73}$ In the revised draft, it is up to the court to make a situational decision. One might consider this to be a lighter alternative in comparison with the original idea of the draft, but no evidence is presented with regard to the effectiveness of this measure in light of the aims of the bill.

The proposed two-year cooling down term in which the perpetrating parent is not allowed to object to the court's prohibition of contact with the children is considered to be a moderate measure. In its (neglected) advice, the Council of State proposed to make courts decide about this term, given the specific circumstances of the case. In some cases, a shorter period could be in the interest of the child. ${ }^{74}$ The proposing MPs do not want to see the perpetrating parent to object to the court within two years because of the child's well-being. Whenever it would be in the child's favour, children - but not the parents - are allowed to go to court. ${ }^{75}$ In the parliamentary debate, two political parties differ about the necessity of the two-year term. The term should be three years (VVD) versus one year (D66). ${ }^{76}$

\subsubsection{Proportionality stricto sensus}

According to the explanatory memorandum, the costs for the new procedure fit into the current budget of the Council for Child Protection. ${ }^{77}$ This keeps the costs out of sight, which makes a true balancing between the costs and benefits impossible. In the parliamentary debate about the proposal, nobody mentioned anything about the costs or benefits. ${ }^{78}$

In the Netherlands, there are fourteen cases of parental intimate partner homicide on average per year. The total amount of children involved in those fourteen cases is twenty-six. As we have seen in most cases, there is no contact between the children and the perpetrating parent against the will of the child. ${ }^{79}$ This means that the new procedure given by this draft could only make a

73. The Council of State refers to the European Convention on Human Rights, Art. 8. As the council stated, according to the convention, the parent's right to access does not depend on the child's interest.

74. Parliamentary proceedings II, 2016-2017, May 10. 2017, at 73-3-1.

75. Parliamentary Papers II 2015-2016 34 518, nr. 4, at 10.

76. Parliamentary proceedings II, 2016-2017, at 73-3-2 and 73-3-5.

77. Parliamentary Papers II 2015-2016 34 518, nr. 3, at 8. According to the explanatory memorandum, there is no need to increase the budget, because of the small amount of cases. For the same reason, the Dutch Council for the judiciary does not expect a substantial increase of the workload.

78. Parliamentary proceedings, 10 May 2017, at 73-3-1 to 73-3-16.

79. In only two out of 84 cases. 


\begin{tabular}{|c|c|c|c|}
\hline & Explanatory memorandum & Council of State & House of Representatives \\
\hline Empirical research & $\begin{array}{l}\text { One study mentioned Only } \\
\text { about impact }\end{array}$ & $\begin{array}{l}\text { Referring to study mentioned } \\
\text { in memo. No other evidence }\end{array}$ & $\begin{array}{l}\text { Referring to study mentioned } \\
\text { in memo. No other evidence }\end{array}$ \\
\hline Suitability & Abstract goals No evidence & $\begin{array}{l}\text { Mentioned study not convinc- } \\
\text { ing about suitability }\end{array}$ & $\begin{array}{l}\text { Implicitly convinced about suit- } \\
\text { ability }\end{array}$ \\
\hline Necessity & $\begin{array}{l}\text { No comparison of regulatory } \\
\text { alternatives }\end{array}$ & $\begin{array}{l}\text { Skip 'No contact, unless' } \\
\text { (adopted). Skip two years' } \\
\text { term to file objections (not } \\
\text { adopted) }\end{array}$ & $\begin{array}{l}\text { Two political parties doubt } \\
\text { need for a court decision in } \\
\text { every case Parties differ about } \\
\text { two years' term (less/more) }\end{array}$ \\
\hline Proportionality stricto sensu & Costs fit into current budget & $\begin{array}{l}\text { Balance between child's well- } \\
\text { being and parent's rights is } \\
\text { questioned Silent about small } \\
\text { number of cases with forced } \\
\text { contact }\end{array}$ & $\begin{array}{l}\text { No comments about costs or } \\
\text { concurring values }\end{array}$ \\
\hline
\end{tabular}

difference for a few cases per year, if it does at all. That makes the balance between the legislative costs and benefits doubtful. It is remarkable that nobody questioned the balancing of the costs and benefits of this legal measure. Even the Council of State kept silent about this. There is no obvious explanation for this. Various possible reasons might be applicable, such as the following: a general feeling that the ends (should) justify the means in this case, the ethical and moral sensitivity of the matter that prevents different actors in the legislative process from critically questioning the costs, but it could also be a simple lack of facts and data about costs and benefits.

The new procedure in the draft limits the possibility of the perpetrating parent to request the Juvenile court for a new decision. This parent has to wait for two years before being allowed to object in court. The drafters expect the child to have less stress as a result of this two years cooling down term. However, there are no empirical data available to estimate whether children would suffer less stress as a result of the new procedure. Here too, there is reasonable doubt about the balance between costs and benefits. Nevertheless, those proposing the bill believe the mentioned balance between the parent's right to contact and the well-being of the child to be an argument in favour of this two-year term. ${ }^{80}$

\subsubsection{Intermediary Conclusion}

The initiators of the draft lean heavily on one particular study, which has as its main outcome that children should not be forced to have contact with the perpetrating parent in order to prevent further trauma.

This single study says little about the suitability of the proposed draft and the more prominent role in the procedure for the Juvenile court because there are only a few cases a year in which children are forced to have contact against their will, and in some cases, it is even the court that decides in favour of forced contact. Other studies have not been included in the explanatory memorandum of the draft.

As far as the necessity of the draft is concerned, there has not been a study of potential alternatives to the proposed procedure. Although the initial idea of a standard two-year cooling down period has been amended because of the criticism by the Council of State, this cannot really be seen as a lighter regulatory alternative. A procedure according to which only the scrutiny of the Council of child protection would be mandatory, might be seen as an alternative, but the consequences of this option have also not been studied.

With regard to costs and benefits of the new procedure, the draft does not provide any serious information. It is claimed that the enactment of the bill will not invoke new costs for the Council of child protection or for Juvenile courts, but it is impossible to verify whether this is actually true based on the evidence provided in the draft.

\section{Conclusion}

Because the idea of evidence-based lawmaking appears to gain increasing support in the circles of lawmakers, ${ }^{81}$ we have undertaken this study to look at the role that empirical evidence plays with regard to the motivation of normative decisions in legislative drafts. We have used the proportionality principle as the lens through which we studied two examples of legislative drafts. In the alcolock case, more quantitative data and research, such as statistics and accident data, were available, while in the intimate partner homicide case, qualitative

81. S. Kealy and A. Forney, 'The Reliability of Evidence in Evidence-Based Legislation', 20(1) European Journal of Law Reform (2018), at 40-66; A. Seidman \& R. Seidman, 'ILTAM: Drafting Evidence-Based Legislation for Democratic Social Change', 9(2) Boston University Law Review (2009), at 435-86. 
research inspired the drafters of new legislation. The research question we raised reads:

To what extent is available empirical research used in explanatory memoranda of two different legislative drafts, namely the introduction of an alcohol lock programme in traffic law and the protection of children in cases of intimate partner homicide, in order to justify normative legal choices, viewed through the lens of the proportionality principle?

We divided this main question into three sub-questions. The first one being whether there is a difference in how the results from qualitative and quantitative studies in the investigated cases play a role in the explanatory memoranda of legislative drafts in order to justify normative choices, judged from a proportionality perspective? Here the answer is clearly negative.

In both our cases, the empirical evidence is primarily used to show the seriousness of the problem, which the draft tries to remedy. Empirical research does not serve to prove the effectiveness of the proposed interventions. ${ }^{82}$ Counter-evidence that might cast doubts as to the suitability, necessity and the balancing of costs and benefits is not presented. In the alcolock case, the draft relies heavily on foreign experiences without much information about the context in which these relatively new programmes operated abroad. In the intimate partner homicide case, the entire draft basically leans on a single study. This study contains no evidence that the proposed procedure to let a court decide about the visitation rights of perpetrating parents with their children will satisfy the aims of the draft. This includes the avoidance of forced contact. In this case, history learns that there have very few occasions where contact between the perpetrating parent and his children was involuntary. In the handful of cases where this was different, it was usually the result of a Juvenile court's order. This would seem to make it unlikely that the proposed measures will prevent forced contact and reduce stress for children. In both cases, there has not been an empirical study of possible lighter regulatory alternatives.

As to the question whether relevant empirical evidence is missing in the explanatory memoranda or not presented in a balanced manner, we can be brief. What is striking in the alcolock case is how little information is provided about the context in which different types of alcolock programmes were functioning abroad. More importantly, however, the drafters neglected the advice to conduct a sound experiment, which was already advised by SWOV - a specialised research institute for traffic safety research - in 1994 as the best way to study the effectiveness of an alcolock programme. This study is not mentioned anywhere in the explanatory memorandum. Taking this into account, it is not surprising that alcolock programmes come out as the best possible

82. This corresponds with earlier findings in research such as: R.A.J. van Gestel \& M.M. Menting, 'Ex ante Evaluation and Alternatives to Legislation: Going Dutch?', 32(3) Statute Law Review (2011), at 1-18. remedy to prevent drunken driving. When drafters only look to research concerning these kinds of programmes and do not include studies of possible regulatory alternatives, these programmes will automatically come out on top. As to the costs of the programme, the Advisory Division of the Council of State already argued that the estimation of costs and benefits was unrealistic. This later turned out to be true when participants of the alcolock programme filed a suit against the government because the regulation violated the proportionality principle due to the fact that the costs for individual participants were unreasonably high.

Regarding the intimate partner homicide case, again not all relevant empirical evidence is presented in the draft, and the evidence that is provided sometimes seems to be interpreted rather one-sidedly. The Utrecht University study, for example, reveals that in $94 \%$ of the cases, the will of the children to not visit the perpetrating parent was respected by the Council of child protection. This raises doubts as to whether the existing procedure should be changed by introducing a mandatory court decision concerning visitation rights. Other comparative studies, not included in the draft, cast doubts with respect to the reliability of the existing empirical data. What is striking is that the Council of State does not seem to be willing or able to critically assess the rather thin evidence on which the draft is based.

Finally, we have to ask ourselves how the lack of attention for empirical (counter-) evidence that does not support the aims of the draft both by the drafters and by organisations responsible for legislative scrutiny, such as the Council of State, can be explained. Vick's explanation that evidence and research that is 'closer' to what lawyers - including legislative drafters - are familiar with does not seem to hold ground in both cases, because there appears to be little difference between how the quantitative research in the alcolock case and the qualitative research in the intimate partner homicide case was dealt with by the drafters. A more likely explanation appears to be that factors other than the methodological closeness of empirical research to the drafters may provide an explanation here. Inspiration might, for example, be drawn from the literature on evaluation use. ${ }^{83}$

With regard to the use of the outcomes of (empirical) evaluations, the literature discerns between instrumental, conceptual and symbolic use. Instrumental use is the direct application of knowledge stemming from research to improve certain policies; conceptual use refers to the situation where no direct action has been undertaken on the basis of the evidence but where people's under-

83. M. Alkin and J. King, 'The Historical Development of Evaluation Use', 37(4) American Journal of Evaluation (2016), at 568-79; B. de Laat \& K. Williams, 'Evaluation use within the European Commission (EC): Lessons for the Evaluation Commissioner', in M. Loud and J. Mayne (eds.), Enhancing Evaluation Use: Insights from Internal Evaluation Units (Thousand Oaks: Sage Publications; 2014), at 147-74; A. Balthasar, 'Institutional Design and Utilization of Evaluation: A Contribution to a Theory of Evaluation Influence Based on Swisse Experience', 33(3) Evaluation Review (2009), at 226-56; D. Fleischer and C. Christie, 'Evaluation Use', 30(2) American Journal of Evaluation (2009), at 158-75. 
standing has been affected; symbolic use concerns the situation in which the mere existence of research or evaluation is used to convince stakeholders rather than any aspect of the outcomes of the research. ${ }^{84}$ Looking at our two cases, one gets the impression that the way in which empirical research is applied in the process of legislative drafting is predominantly 'symbolic'. This would indicate that it is not the type of research, the methodological closeness to lawyers, the validity of the research or the conclusiveness of the outcomes that determines whether empirical research will be taken into account. Instead, empirical research appears to be primarily used to defend politically desired outcomes.

Especially in the more sensitive case of the intimate partner homicide, legislative drafters might realise that, for example, State Councillors and MPs will find it very difficult to critically assess research that claims to support victims of a horrible crime. On a deeper level, as Rachlinski has argued, evidence-based law is problematic in itself, ${ }^{85}$ because the scientific rationality in the legislative process often conflicts with deeply held moral and political beliefs. The question is to what extent one may expect from legislative drafters acting on behalf of a politically responsible minister that they are going to use empirical evidence running against the normative (e.g. moral, ideological, political) choices of their political superiors? Is it not more likely that draftsmen will be inclined to look for facts, arguments and empirical research that can be used to support the passing of the draft, while leaving the counter-arguments and counterevidence to the opposition in Parliament?

In case the latter would be true, we believe our proposal to assess legislative drafts through the lens of our proportionality test becomes all the more important. Not only is it a way to systematically study how empirical data and scientific evidence are used to prove that proposals for new legislation are suitable to accomplish the aims of the draft, the necessity of the interventions and the balancing of costs and benefits, but it can provide courts afterwards with valuable information to strike down pieces of legislation that infringe upon the rights of citizens in a disproportionate manner because empirical data and scientific evidence with regard to the proposed solution to certain policy problems were ignored. In other words, courts opting for a process-oriented review could perhaps benefit from the fact that during the preparatory phase, the outcomes of the proportionality test were set aside. By doing so, the ex post evaluation of legislation by courts and the ex ante evaluation of legislative drafts by legislative scrutiny boards, such as the Council of State, might re-enforce each other. In case both draftsmen and political actors start to realise that courts will no longer shy away from a stringent proportionality review, they could become more careful with the way in which empirical data and scientific evidence are used to promote new pieces of legislation. 